Б.А. Кутний, канд. техн. наук, доц., ОRCID 0000-0002-0548-7925 Івано-Франківський національний технічний університет нафти і газу A.М. Павленко, д-р техн. наук, проф., ORCID 0000-0002-8103-2578 Келецький технологічний університет (Польща)

\title{
МАТЕМАТИЧНЕ МОДЕЛЮВАННЯ ФАЗОВОПЕРЕХІДНИХ ПРОЦЕСІВ У ГАЗО-РІДИННИХ СИСТЕМАХ
}

Роботу присвячено дослідженню перехідних тепломасообмінних процесів щзо відбуваються $у$ рідині, яка оточує газопарову бульбашку. Запропоновано числовий метод рішення, який дозволяє розраховувати температурні поля у рідині з урахуванням фазових переходів, руху стінки бульбашки та теплообмінних прочесів біля ї̈ поверхні. Також враховано зміну теплофізичних характеристик рідини при зміні ї температури. Наведено результати математичного моделювання теплообмінних процесів при розширенні та стисканні бульбашки. Порівняння мас промерзлих шарів показує, що при розщиренні бульбашки інтенсивність фазовоперехідних процесів у рідині підвищується, а при стисканні знижується, у порівнянні з нерухомою стінкою бульбашки. Аналіз отриманих результатів математичного моделювання показав, щуо вони є прогнозованими й повністю відповідають фізичним уявленням про перебіг теплообмінних та фазовоперехідних процесів у рідині. Розроблена математична модель може застосовуватися для оптимізації різноманітних технологічних процесів пов'язаних $з$ кавітацією, кипінням та утворенням газових гідратів.

Ключові слова: теплофізичні характеристики рідини, газопарова бульбашка, теплообмін в двохфазному середовищі, фазові перетворення.

\section{1. Вступ}

В багатьох технологічних процесах газопарові бульбашки відіграють головну роль. В якості прикладу зазначимо наступні технології: дегазація води, перегонка нафтопродуктів, очищення поверхонь кавітацією, гомогенізація палива, змішування колоїдних розчинів, піноутворення в харчовій промисловості, тощо. Сучасні технології виготовлення теплоізоляційних матеріалів [1], опріснення морської води за допомогою гідрату ізобутану [2-4], отримання гідрату природного газу [5, 6] для транспортування та зберігання також грунтуються на тепломасообмінних процесах в газорідинних системах.

Зазвичай утворення та існування газопарових бульбашок супроводжується інтенсивними теплообмінними, масообмінними та фазовоперехідними процесами. Складність здійснення «прямих» спостережень (малі розміри бульбашок, висока швидкість процесів) зумовили широке застосування методів математичного моделювання для дослідження. Математичні моделі дозволяють визначити найбільш впливові фактори та оптимізувати технологічні процеси. Коректність математичних моделей газопарових бульбашок визначається точністю урахування всіх теплофізичних процесів у рідині та газі.

Як правило, відомі методи розрахунку тепломасообмінних процесів такого типу лише наближено враховують температурний режим рідини та фазовоперехідні процеси, що відбуваються навколо газопарових бульбашок. Урахування перехідних процесів у рідині дозволить суттєво підвищити точність розрахунку та розширити межі застосування таких математичних моделей. Саме тому дослідження в даному напрямку є надзвичайно актуальними.

\section{2. Аналіз літературних даних та постановка проблеми}

Для підвищення точності моделювання теплообмінних процесів у газопаровій бульбашці необхідно враховувати перенесення теплоти в середовищі рідини. Ряд авторів приймають температуру рідини постійною: при розрахунку спучення матеріалів [1], при визначенні термодинамічних характеристик парових [7] та кавітаційних бульбашок [8]. В роботі [9] температура рідини описується експоненційною функцією, котра не залежить від часу та напрямку руху стінки бульбашки. Деякі автори [10] вважають теплообмінний шар рідини настільки тонким, що кривизну поверхні бульбашки можна не враховувати. Проте, такі припущення можливі лише для дуже обмеженої групи задач. В роботі [11] для кавітаційних та в роботі [12] для парових бульбашок, наведено аналітичне вирішення задачі нестаціонарної теплопровідності в шарі рідини, що оточує осцилюючу бульбашку. Внаслідок введених автором припущень, у рішенні даної

(с) Б.А. Кутний, А.М. Павленко, 2019 
задачі отримано розв'язок, у якому теплообмінний шар рідини рівний радіусу бульбашки і не залежить від теплофізичних характеристик рідини. В роботі [13] враховано лише теплопровідність в рідині, без урахування фазовоперехідних процесів. Огляд вищенаведених літературних джерел показує, що фазовоперехідні процеси в рідині, яка оточує газовопарову бульбашку, досліджені недостатньо.

Температурний режим газу всередині бульбашки може змінюватися у широких межах: від температури нижчої за температуру замерзання рідини у періоди «росту» бульбашки до температури вищої за температуру кипіння рідини в періоди стискання бульбашки. Зміна фазового стану рідини призводить до значної зміни тепломасообмінних процесів на їі границі.

Для розширення меж математичного моделювання газопарової бульбашки необхідно врахувати фазовоперехідні процеси теплопередачі в рідині, що оточує газопарову бульбашку. Внаслідок цього теплофізичні характеристики речовини на границі 3 бульбашкою можуть суттєво змінюватися. Особливостями даної задачі є рух стінки бульбашки, швидкість якої, в окремі моменти часу може сягати декількох десятків метрів за секунду.

\section{3. Мета і завдання дослідження}

Мета статті полягає у створенні математичної моделі передачі теплоти в рідині яка оточує осцилюючу газопарову бульбашку. Ця математична модель повинна враховувати рухливість стінки бульбашки, можливість фазовопрехідних процесів у шарах рідини та зміну іï теплофізичних характеристик. Для перевірки працездатності математичної моделі в різних умовах необхідно виконати ряд розрахункових експериментів та проаналізувати отримані результати.

\section{4. Математична модель фазовоперехідних процесів у рідині}

Для розробки математичної моделі теплопередачі в рідині застосовано наступні спрощуючі припущення:

- біля поверхні бульбашки задано граничні умови другого роду;

- газопарова бульбашка має сферичну форму і оточена безкінечною кількістю рідини;

- центр бульбашки відносно рідини не переміщується.

Для визначення температури в товщі рідини, яка оточує газопарову бульбашку, необхідно розглянути процес теплопередачі в рідині. Для розрахунку теплопередачі шляхом теплопровідності зазвичай застосовують рівняння теплопровідності Фур'є, а урахувати конвекцію можна використовуючи ефективний коефіцієнт теплопровідності.

Позначимо через «x» координату, по якій змінюється радіус бульбашки. Для визначення невідомої температури на поверхні бульбашки та в масиві рідини $\left(T_{(x, \tau)}\right)$ можна застосувати нелінійне рівняння теплопровідності Фур'є для кулі з урахуванням рухливості їі стінок [9] та дії об’ємних джерел теплоти

$$
\frac{\partial\left(\rho_{r} c_{r} T_{(x, \tau)}\right)}{\partial \tau}+\theta^{\lambda\left(\sim \boldsymbol{T}_{(x, \tau)}\right)}=\frac{1}{x^{2}} \frac{\partial}{\partial x}\left(\lambda_{r} x^{2} \frac{\partial T_{(x, \tau)}}{\partial x}\right)+q_{v(x, T)},
$$

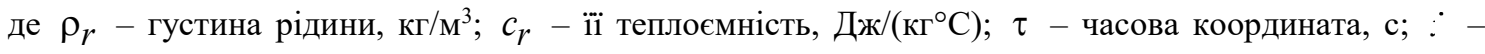
швидкість зміни радіуса бульбашки, м/с; $\lambda_{r}$ - ефективний коефіцієнт теплопровідності рідини, Вт/( $\left.{ }^{\circ} \mathrm{C}\right)$; $q_{v}$ - потужність об'ємних джерел теплоти, Вт/м³. В результаті теплообмінних процесів на границі бульбашки рідина може змінювати свої теплофізичні характеристики, тому задачу будемо розв'язувати як нелінійну. Застосування джерел теплоти робить рівняння (1) неоднорідним.

Зважаючи на те, що біля поверхні бульбашки відомий питомий тепловий потік $(q)$, запишемо граничну умову другого роду

$$
-\frac{\partial \lambda_{r} T_{(R, \tau)}}{\partial x}=q_{(R, \tau)}
$$

Рівняння (2) враховує зміну коефіцієнту теплопровідності на границі бульбашки, наприклад у разі замерзання рідини.

В такій постановці задачу зручно розв'язувати методом кінцевих елементів. Для опису теплопровідності в рідині, яка оточує бульбашку радіусом $\mathrm{R}$, розділимо шар рідини на ряд концентричних оболонок $(i)$, рис. 1. Задамо розподіл мас кожної оболонки

$$
m_{r(2)}=2 K_{r} m_{r(1)}, \quad m_{r(i)}=K_{r} m_{r(i-1)}
$$


де $m_{r(1)}$ - маса оболонки 1-го (внутрішнього) шару, кг; $m_{r(i)}$ - маса кожної наступної оболонки, кг; $K_{r}$ - коефіцієнт пропорційності. Цей коефіцієнт дозволяє «згустити» сітку елементів біля границі бульбашки і «розрідити» в більш глибинних шарах рідини. Він застосовується для оптимізації розрахунків і його типові значення знаходяться в межах 1,5-2.

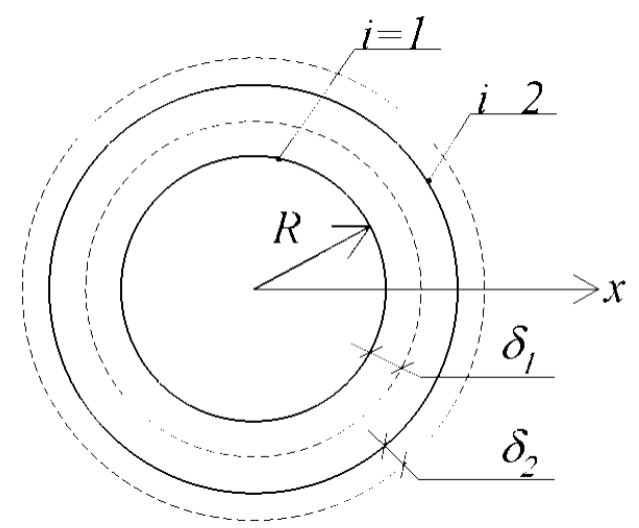

Рисунок 1 - Схема поділу рідини на ряд концентричних оболонок

Визначимо температуру на внутрішній поверхні першої (внутрішньої) оболонки. Для цього запишемо загальне диференційне рівняння ії теплового балансу

$$
m_{r(1)} c_{r(1)} \frac{d T_{(R, \tau)}}{d \tau}=-F_{R} q_{(R, \tau)}+\frac{4 \pi \lambda_{r(1)}\left(T_{(R+\delta 1, \tau)}-T_{(R, \tau)}\right)}{\frac{1}{r_{(1)}}-\frac{1}{r_{(1)}+\delta 1}}+r_{\Phi} \frac{d m_{\Phi(1)}}{d \tau} .
$$

де $c_{r(1)}$ - теплоємність середовища 1-ї оболонки, Дж/(кг $\left.{ }^{\circ} \mathrm{C}\right) . F_{R}$ - площа теплообмінної поверхні, $\mathrm{M}^{2} ; r_{\Phi}$ - теплота фазового переходу, Дж/кг; $m_{\Phi(1)}$ - маса твердої фази оболонки 1-го (внутрішнього) шару, кг. Остання складова рівняння (4) існує лише за наявності фазового переходу.

Аналогічним чином можна записати диференційні рівняння для усіх наступних оболонок

$$
m_{r(i)} c_{r(i)} \frac{d T_{(x, \tau)}}{d \tau}=\frac{4 \pi \lambda_{r}\left(T_{(i-1)}-T_{(i)}\right)}{\frac{1}{r_{(i-1)}}-\frac{1}{r_{(i)}}}-\frac{4 \pi \lambda_{r}\left(T_{(i)}-T_{(i+1)}\right)}{\frac{1}{r_{(i)}}-\frac{1}{r_{(i+1)}}}+r_{\Phi} \frac{d m_{\Phi(i)}}{d \tau} .
$$

В окремі моменти часу в різних оболонках можуть створюватися сприятливі умови для здійснення фазового переходу. При цьому потрібно враховувати три складових: температурний режим, масу твердої та рідкої фаз, дію об'ємних джерел теплоти. Умови фазового переходу першого роду складаються з двох частин: умова намерзання льоду та умова танення льоду. Умова намерзання льоду

$$
T_{\left(r_{i}, \tau\right)} \leq T_{\Phi} \text { та } m_{\Lambda\left(r_{i}, \tau\right)}<m_{\left(r_{i}, \tau\right)} \text { та } Q_{\Phi\left(r_{i}, \tau\right)}>0
$$

де $T_{\Phi}$ - температура фазового переходу, ${ }^{\circ} \mathrm{C} ; m_{\Lambda}\left(r_{i}, \tau\right)$ - маса твердої фази в і-му шарі у будь-який момент часу, кг; $Q_{\Phi}\left(r_{i}, \tau\right)$ - тепловий потік, який відводиться з і-го шару для здійснення фазового переходу, Вт.

Умова танення льоду

$$
T_{\left(r_{i}, \tau\right)} \geq T_{\Phi} \text { та } m_{\Lambda\left(r_{i}, \tau\right)}>0 \text { та } Q_{\Phi\left(r_{i}, \tau\right)}<0
$$

Якщо у і-му шарі відбувається фазовий перехід, то температура цього шару не змінюється і 


$$
\frac{d T_{\left(r_{i}, \tau\right)}}{d \tau}=0
$$

У цьому випадку потужність об’ємних джерел теплоти можна визначити за формулою

$$
q_{v(i)}=\frac{4 \pi}{V_{r(i)}}\left(K_{3}\left(T_{\left(r_{i}, \tau\right)}-T_{\left(r_{i}-\delta i, \tau\right)}\right)-K_{1}\left(T_{\left(r_{i}+\delta i, \tau\right)}-T_{\left(r_{i}, \tau\right)}\right)\right) .
$$

Аналогічним чином можна знайти потужність об'ємних джерел теплоти для 1-ї оболонки

$$
q_{v(1)}=\frac{4 \pi}{V_{r(1)}}\left(R^{2} q-K_{1}\left(T_{(R+\delta 1, \tau)}-T_{(R, \tau)}\right)\right) .
$$

Знаючи інтенсивність об’ємних джерел можна визначити зміну маси твердої фази.

$$
m_{\Lambda\left(r_{i}, \tau+\Delta \tau\right)}=m_{\Lambda\left(r_{i}, \tau\right)}+\frac{q_{v(i)} \cdot \Delta \tau \cdot V_{r(i)}}{r_{\Phi}} .
$$

У разі фазового переходу в $i$-му шарі рідини буде відбуватися зміна теплофізичних властивостей. Тому, на кожному ітераційному крокові теплофізичні характеристики шарів необхідно уточнювати за формулами:

- середня густина водо-льодяної суміші $i$-го шару

$$
\rho_{r(i)}=\frac{\rho_{\Lambda(i)} m_{\Lambda(i)}+\rho_{w(i)}\left(m_{(i)}-m_{\Lambda(i)}\right)}{m_{(i)}} ;
$$

- середня теплопровідність водо-льодяної суміші $i$-го шару

$$
\lambda_{r(i)}=\frac{\lambda_{\Lambda(i)} m_{\Lambda(i)}+\lambda_{w(i)}\left(m_{(i)}-m_{\Lambda(i)}\right)}{m_{(i)}} ;
$$

Зміна густини, при постійній масі, призведе до зміни розміру шарів, що може ускладнити розрахунковий процес. Враховуючи, що густина і теплоємність в формулі (1) застосовуються у вигляді добутку, зміну густини можна замінити еквівалентною зміною теплоємності. Це дозволяє отримати точне значення температури при незначній помилці в координаті. Наприклад, для фазового переходу вода-лід така помилка не перевищує 3\%. 3 урахуванням поправки на густину теплоємність і-го шару визначається за формулою

$$
c_{r(i)}=\frac{\rho_{r(i)}}{\rho_{w}} \times \frac{c_{\Lambda(i)} m_{\Lambda(i)}+c_{w(i)}\left(m_{(i)}-m_{\Lambda(i)}\right)}{m_{(i)}},
$$

де $\rho_{w}$ - густина рідини при початковій температурі, кг/м³. У цьому випадку густина усіх шарів задається однаковою $\rho_{r(i)}=\rho_{w}$.

Для розв'язку системи диференційних рівнянь (4) та (5) застосовується метод Рунге-Кутта 4-го порядку [14]. 3 метою оцінки адекватності розробленої математичної моделі була написана комп'ютерна програма і виконано ряд математичних експериментів. Результати розрахунку відображено в наступних дослідах.

\section{5. Результати досліджень фазовоперехідних процесів у рідині}

Розглянемо тепломасообмінні процеси в рідині на початковому етапі барботажного введення бульбашок газу у воду [15]. Технологічно такі процеси характерні для карбонування [16], утворення гідрату ізобутану [17] та інших гідратів [18-20]. Тривалість розрахункового інтервалу часу 3-6 мкс (мікросекунд). Часовий крок $0,005-0,01$ нс, питомий тепловий потік біля поверхні бульбашки (гранична умова $2-$-г роду) $1 \mathrm{MBT} / \mathrm{M}^{2}$. Початковий діаметр бульбашки 0,1 мм, початкова температура води $+0,5^{\circ} \mathrm{C}$. 
Розрахункових шарів 12 , коефіцієнт $K_{r}=1,5$. Початкові значення теплопровідності, густини і теплоємності води прийняті при температурі $+0,5^{\circ} \mathrm{C}$. Теплота фазового переходу вода-лід 335 кДж/кг. Температура парогазового середовища реальної бульбашки може змінюватися в досить широких межах. Для дослідження фазовоперехідних процесів у воді бульбашку з температурою парогазового середовища нижчою за температуру фазового переходу будемо називати «холодною». Бульбашку 3 температурою парогазового середовища вищою за температуру фазового переходу назвемо «гарячою».

Дослід № 1. Розглянемо бульбашку у воді що утворилася при барботажному дроселюванні газу через щілясту насадку. Внаслідок ефекту Джоуля-Томпсона температура газу в бульбашці є нижчою за температуру оточуючої рідини. Вважаючи тиск газу в бульбашці рівним тиску води (з урахуванням сил поверхневого натягу), приймемо швидкість руху стінок бульбашки рівною 0 м/с. Результати розрахунку температурного режиму рідини, яка оточує «холодну» бульбашку, зображено на рис. 2.

Дослід № 2. Якщо тиск газу в бульбашці перевищує тиск рідини - бульбашка розширяється. Розглянемо процеси в рідині під час розширення «холодної» бульбашки зі швидкістю стінки 10 м/с, оскільки така швидкість $\epsilon$ характерною для резонансного режиму осциляцій бульбашки. Результати розрахунку зображено на рис. 3 .

Дослід № 3. В процесі осциляції фаза розширення бульбашки змінюється фазою стиснення. Розглянемо процеси в рідині в період стиснення бульбашки з «холодним» газом зі швидкістю стінки -10 м/с. Результати розрахунку зображено на рис. 4.

Під час періоду стискання бульбашки температура газу в ній підвищується і створюються сприятливі умови для танення льодяної кірки, що утворилася в попередніх стадіях осциляції бульбашки. 3 часом рух стінки бульбашки сповільнюється і починається процес розширення в умовах підвищеної температури газу. Наступна серія розрахунків проведена для дослідження фазовоперехідних процесів навколо «гарячої» бульбашки.

6. Обговорення результатів математичного моделювання фазовоперехідних процесів у рідині

Верхня частина рис. 2 показує порівняно швидке охолодження рідини до температур, близьких до температури фазового переходу $\left(0^{\circ} \mathrm{C}\right)$. Сам фазовий перехід спостерігаємо у вигляді майже горизонтальної площадки приблизно по центру діаграми. Ліва частина діаграми відображає процес охолодження льоду. Ступінчастий характер температури льоду пояснюється невеликою кількістю розрахункових шарів (12 шт.). За 2,0 мкс глибина промерзання склала 5 розрахункових шарів рідини навколо бульбашки.

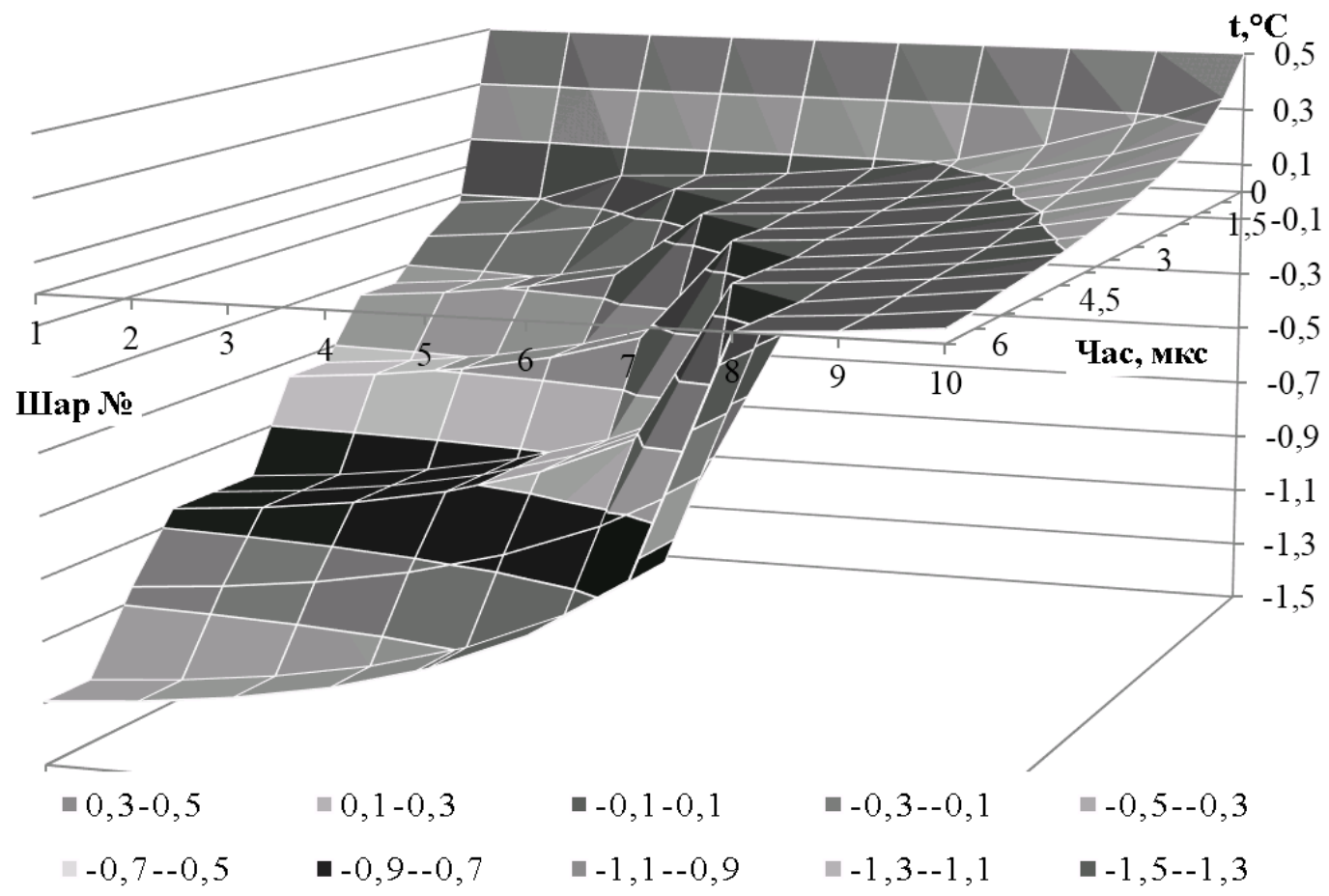

Рисунок 2 - Діаграма температурних полів у воді, що оточує «холодну» бульбашку з нерухомою стінкою $\left(\begin{array}{ll}\dot{R} & \mathrm{M} / \mathrm{c}\end{array}\right)$.

Як бачимо на рис. 3, за 2 мкс глибина промерзання склала 6 шарів рідини. Порівняння мас промерзлих шарів досліду 1 та 2 показує, що при розширенні бульбашки промерзання рідини відбувається 
скоріше приблизно у 1,6 рази. Це відбувається внаслідок збільшення площі теплообмінної поверхні при збільшенні розміру бульбашки. У лівій частині діаграми температура льоду має зубчастий характер. Невеликий підйом температури спостерігається внаслідок зменшення товщини і термічного опору оболонок у процесі розширення бульбашки. Загалом зменшення товщини оболонок з твердою фазою призводить до того, що температура поверхні бульбашки знаходиться ближче до температури фазового переходу, аніж у 1-му досліді.

Наведені на рис. 4 результати розрахунку стиснення «холодної» бульбашки показують, що у цьому випадку процес промерзання рідини значно сповільнюється. Зокрема товщина льоду склала лише 60 \% від варіанту з нерухомою стінкою бульбашки. Це пояснюється зменшенням площі теплообмінної поверхні. Внаслідок збільшення товщини промерзаючих шарів відбувається підвищення термічного опору i температура на внутрішній поверхні бульбашки знижується скоріше, аніж у дослідах 1 та 2.

Результати розрахунку нерухомої «гарячої» бульбашки показують порівняно швидке початкове прогрівання шарів льоду до температури фазового переходу. Порівнюючи результати 3 дослідом № 1 можна відмітити що процес танення відбувається майже з тією-ж швидкістю, що і процес замерзання. Цьому сприяє гранична умова 2-го роду. Майже у чотири рази менша теплопровідність води порівняно 3 льодом, призводить до більш інтенсивного нагрівання міжфазної поверхні рідина-газ.

Результати розрахунку стискання «гарячої» бульбашки показують значне сповільнення процесу танення льоду порівняно з їі розширенням. Температура внутрішніх шарів води зростає значно скоріше ніж у дослідах з розширенням бульбашки. Цьому сприяють як збільшення товщини шарів води при стисненні бульбашки, так і значно менша теплопровідність води порівняно з льодом (приблизно в 4 рази). Зменшення кількості льоду, який розтав пояснюється зменшенням площі поверхні теплообміну і як наслідок, зменшенням загальної кількості теплоти, котра підводиться до міжфазної поверхні бульбашки.

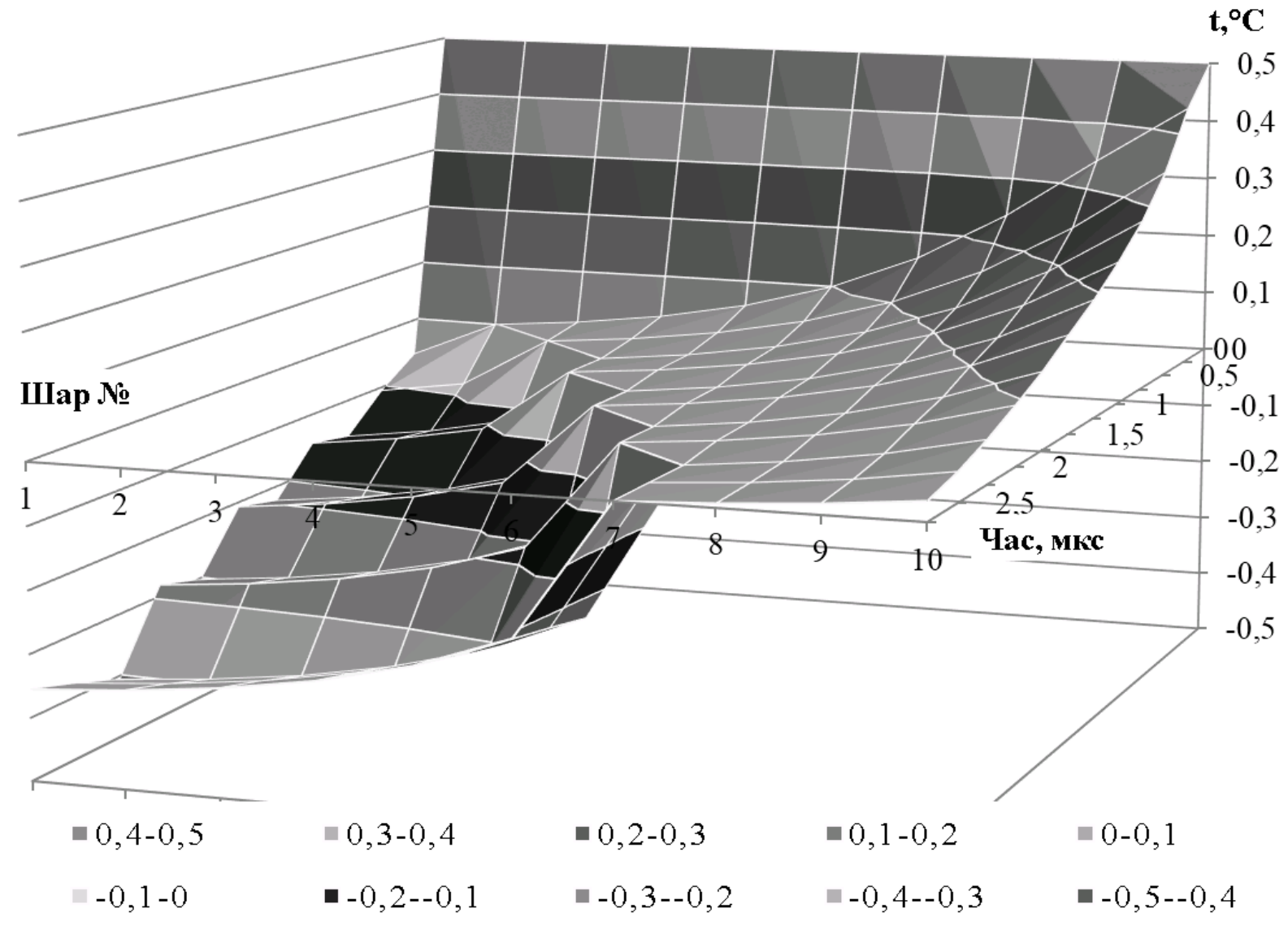

Рисунок 3 - Діаграма температурних полів у воді, що оточує «холодну» бульбашку, яка розширяється зі швидкістю $\dot{R} \quad \mathrm{M} / \mathrm{c}$. 


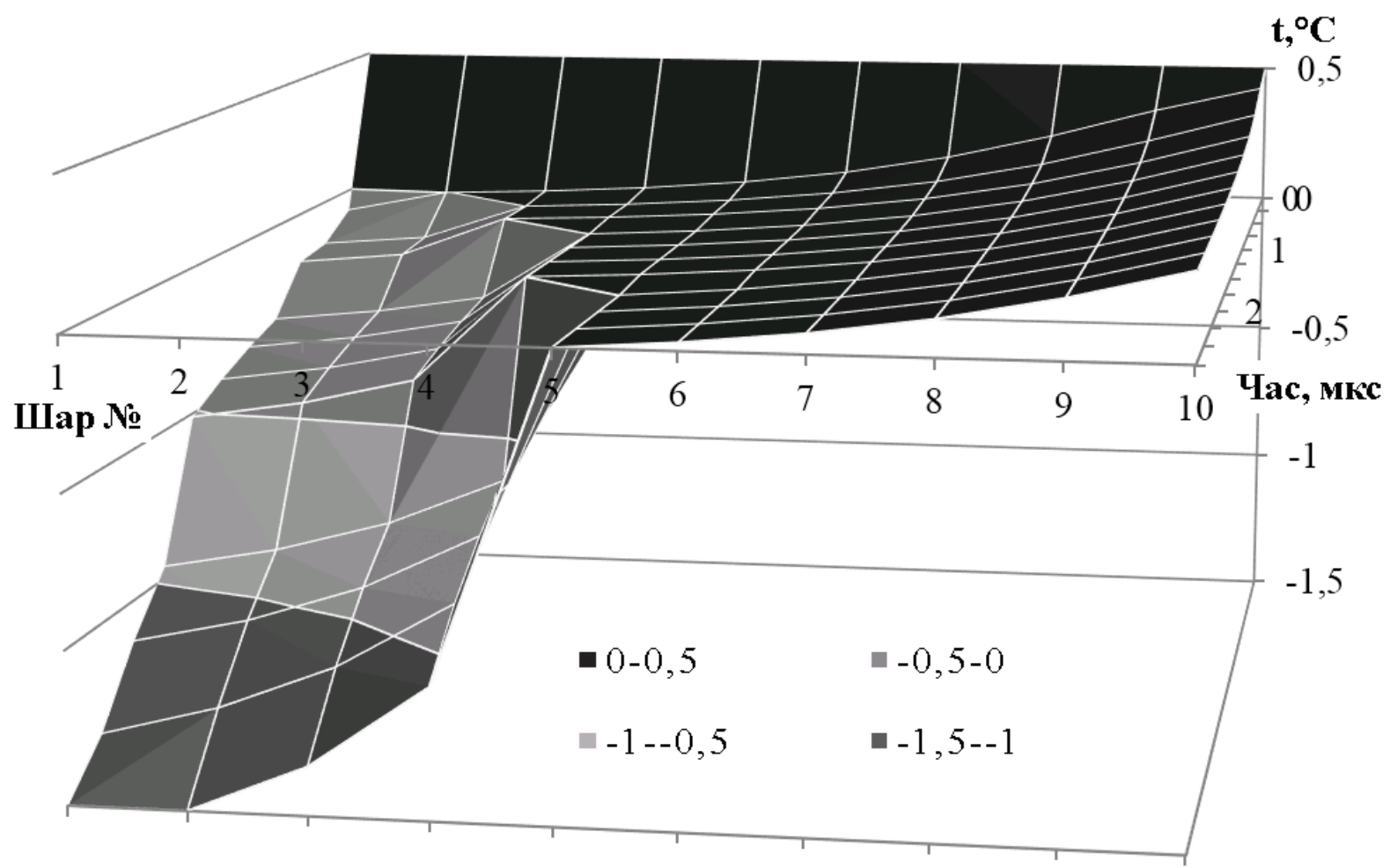

Рисунок 4 - Діаграма температурних полів у воді, що оточує «холодну» бульбашку, яка стискається на швидкості $\dot{R} \quad \mathrm{M} / \mathrm{c}$.

Таким чином, за допомогою математичного моделювання отримано розподіл температурних полів у рідині в умовах фазовоперехідних процесів та зміни розміру бульбашки. Виконані дослідження показують що, застосований метод кінцевих елементів (3)-(13), для математичної моделі нестаціонарної передачі теплоти в рідині (1)-(2), яка оточує осцилюючу газопарову бульбашку коректно відображає фізичні процеси. Вона враховує зміну теплофізичних характеристик рідини (11)-(13), зміну розміру бульбашки (4)-(5), теплообмінні процеси на ії границі (4) та фазовоперехідні процеси у товщі рідини (6)(10). Створену математичну модель можна використовувати для оцінки термодинамічних параметрів двофазної рідини у різних технологічних процесах.

Запропонована методика розрахунку може застосовуватися для визначення теплофізичних характеристик рідини та пари у різноманітних технологічних процесах, пов'язаних з розчиненням газів у рідині, твердінням піни та утворенням газових гідратів.

\section{7. Висновки}

В статті розроблено математичну модель нестаціонарної теплопровідності рухливої стінки бульбашки, яка враховує зміну агрегатного стану та теплофізичних характеристик речовини. Показано, що при застосуванні методу кінцевих елементів вона представляє собою систему нелінійних диференційних рівнянь 1-го порядку. Урахування в математичній моделі зазначених особливостей дозволяє у будь-який момент часу отримувати значення температур рідкої та твердої фаз при зміні розміру бульбашки, зміні напрямку теплового потоку на їі границі. Для аналізу коректності математичного моделювання перехідних процесів у рідині виконано ряд оціночних розрахунків (дослідів). Їх суть полягала у перевірці відтворення математичною моделлю різних термодинамічних умов та режимів газопарової бульбашки: нагрівання i охолодження разом з фазовоперехідними процесами, стискування та розширення. Для кожного досліду побудовано діаграму температурних полів у речовині, що оточує газопарову бульбашку.

Наведені в роботі результати розрахунку для нерухомої бульбашки діаметром 0,1 мм при граничній умові 2-го роду показують, що швидкість намерзання льоду і швидкість його танення майже рівні, проте температура на міжфазній поверхні газ-вода приблизно у чотири рази більша за температуру поверхні газлід, що відповідає співвідношенню теплопровідності води та льоду. Температура в області фазового переходу рідина-лід практично постійна. Порівняння мас промерзлих шарів свідчить проте, що при розширенні бульбашки промерзання рідини та танення льоду відбувається скоріше ніж у нерухомій бульбашці приблизно у 1,6 рази. При стисканні бульбашки товщина льоду, що утворився чи розтанув приблизно в 1,7 рази менша порівняно з нерухомою стінкою бульбашки.

Таким чином, аналіз отриманих результатів показав, що вони є прогнозованими і повністю 
відповідають фізичним уявленням про перебіг теплообмінних та фазовоперехідних процесів у рідині, а запропонована математична модель може застосовуватися для їх розрахунку.

\section{Список використаної літератури}

1. Pavlenko, A. M. Regularities of boiling-up of emulsified liquids / A. M. Pavlenko, B. I. Basok // Heat Transfer Research, - 2005. 36 (5), - pp. 419.

2. Якушев, В. С. Современное состояние газогидратных технологий / В. С. Якушев, В. Г. Квон, Ю. А. Герасимов, В. А. Истомин // - М.: ООО «ИРЦ Газпром», - 2008. - 88 с.

3. Takeya, S. Self-preservation effect and dissociation rates of CH4 hydrate / S. Takeya, T. Ebinuma, T. Uchida et al. // J. Crystal Growth. - 2002. - V.237-239. - P. 379-382.

4. Stem, L.A. Temperature, pressure and composition effects on anomalous or "self preservation of gas hydrates / L.A. Stem, S. Circone, S.H. Kirby, W.B. Durham // Can. J. Phys. - 2003. - V.81. - P. $271-283$.

5. Behkish, A. Novel correlations for gas holdup in large-scale slurry bubble column reactors operating under elevated pressures and temperatures / A. Behkish, R. Lemoine, R. Oukaci, B. I. Morsi // Chemical Engineering Journal. - 2006. Vol. 115, - P. 157-171.

6. Shahrzad Hashemi Dynamic Simulation of Gas Hydrate Formation in an Agitated Three-Phase Slurry Reactor / Hashemi Shahrzad, Macchi Arturo, Servio Phillip // The 12th International Conference on Fluidization - New Horizons in Fluidization Engineering. - 2007. Art. 39. - P. 329-336.

7. Шагапов В. Ш. К теории роста паровых пузырьков в метастабильной жидкости / В. Ш. Шагапов, В. В. Коледин // Теплофизика высоких температур / Институт механики Уфимского научного центра РАН. - 2013, том 51. - № 4. - С. 543-551.

8. Веретельник Т. И. Математическое моделирование кавитационного потока жидкости в химикотехнологической системе / Т. И. Веретельник, Ю. Н. Дифучин / Черкаський державний технологічний університет // Вісник ЧДТУ. - Черк., - 2008. - №3. - С. 82 - 85.

9. Актершев С. П. Моделирование вскипания метастабильной жидкости при наличии фронтов испарения [Текст] / С. П. Актершев, В. В. Овчинников // Современная наука: исследования, идеи, результаты, технологи. - Новосибирск: Институт теплофизики им. С.С.Кутателадзе СО РАН. $-2013 .-$ №1. - C. $77-82$.

10. Нигматулин Р. И. Динамика и тепломассообмен парогазовых пузырьков с жидкостью [Текст] / Р. И. Нигматулин, Н. С. Хабеев // Некоторые вопросы механики сплошной среды. (посвящено 70-летию акад. Л.И.Седова). М.: Ин-т механики МГУ, - 1978. - С. 229-243.

11. Кулінченко В. Р. Передумови створення математичної моделі - основні положення і рівняння руху Релея / В. Р. Кулінченко, В. Л. Зав’ялов, Т. Г. Мисюра // Наукові праці Національного університету харчових технологій. - 2007. - №22. - С. 36-41.

12. Долинский А. А. Теоретическое обоснование принципа дискретно-импульсного ввода энергии. Модель динамики одиночного парового пузырька / А. А. Долинский, Г. К. Иваницкий // Пром. теплотехника. - 1995. Т.17, - №5. - С. 3-28.

13. Pavlenko, A.M., Basok, B.I. (2005). Kinetics of water evaporation from emulsions / A.M. Pavlenko, B.I. Basok // Heat Transfer Research. 36, (5), - P. 425-430.

14. Butcher, J. C. Numerical Methods for Ordinary Differential Equations / J. C. Butcher - New York: John Wiley \& Sons, - 2008. - pp. 482.

15. Кушнір, С. В. Барботажні хімічні ефекти: їх види, механізми виникнення та геохімічні прояви / С. В. Кушнір, М. В. Кость, Р. П. Козак / Інститут геології і геохімії горючих копалин НАН України, м. Львів: Вода і водоочисні технології. Наково-технічні вісті №3 (20), - 2016. - С. 30-47.

16. Ермолаева, Г. А. Технология и оборудование производства пива и безалкогольных напитков / Г. А. Ермолаева, Р. А. Колчева // Учеб. для нач. проф. образования. - М.: ИРПО; Изд. центр «Академия», 2000. $-416 \mathrm{c}$.

17. Мосин, О. В. Физико-химические основы опреснения морской воды / О. В. Мосин // Сознание и физическая реальность, - 2012, - № 1, - С. 19-30.

18. Семенов, М. Е. Синтез гидратов газов лабораторных условиях / М. Е. Семенов, Е. Ю. Шиц // Технические науки - от теории к практике: сб. ст. по матер. XVII междунар. науч.-практ. конф. Часть II. Новосибирск: СибАК, - 2013. - С. 55-61.

19. Okutani, K. Surfactant effects on hydrate formation in an unstirred gas/liquid system: An experimental study using methane and sodium alkyl sulfates / K. Okutani, Y. Kuwabara, Y. Mori // Chemical Engineering Science,. - 2008. V.63. P. 183-194

20. Мельников В. П. Релаксационный ямр-анализ фазовых превращений воды в дисперсной системе вода/гидрат фреона -12/углеводород при диссоциации гидрата / В. П. Мельников, ЈI. С. Поденко, А. Н. Нестеров, А. М. Решетников // ДАН., - 2010. Т.433. - №1. - С. 59-61. 
B. Kutnyi, $\mathrm{PhD}$, Associate Professor ORCID 0000-0002-0548-7925 Ivano-Frankivsk National Technical University of Oil and Gas A. Pavlenko, Dr. Sc. Sciences., Prof. ORCID 0000-0002-8103-2578 Politechnika Świętokrzyska MATHEMATICAL MODELING OF PHASE-TRANSFER PROCESSES IN GAS-LIQUID SYSTEMS

The results of designing the mathematical model of non-stationary thermal conductivity of the bubble's oscillating wall, with account of the changes in the aggregate state and the thermal and physical characteristics of the substance, are presented. It is shown that when applying the finite elements method, it is a system of nonlinear differential equations of the 1st order. Consideration of these features in the mathematical model allows obtaining the temperature values of liquid and solid phases at any time when changing the bubble's size and the heat flow direction at its boundary.

Based on the suggested mathematical model, a series of assessment calculations was performed. Applying mathematical modeling, the temperature fields' distribution in the liquid under the conditions of the phase transition processes and changes in the bubble size is obtained. The performed studies show that for an immobile bubble under the boundary condition of the 2nd kind, the icing and ice melting velocities are almost equal, but the temperature on the interphase gas-water surface is approximately four times exceeding the temperature on the gas-ice surface, which corresponds to the water and ice thermal conductivity ratio. The temperature in the phase liquid-ice transition zone is practically constant. With the expansion of the bubble, liquid freezing and ice melting are going more than 1.6 times faster than in the immobile bubble. The analysis of the results obtained has shown that they are predictable and fully correspond to the physicists' ideas of the heat transfer and phase transition processes flow in the liquid.

The suggested calculation method can be used to determine the thermal characteristics of the liquid and steam in various technological processes associated with gases dissolution in the liquid, foam hardening and gas hydrates formation. The mathematical model designed can be applied as a component for calculation of more complicated physical processes. The study results can be applied to optimize various technological processes associated with materials swelling, gases adsorption, liquids boiling and gas hydrates formation.

Keywords: thermal and physical characteristics of liquid, gas-to-steam bubble, heat transfer in two-phase medium, phase transformations.

\section{References}

[1] Pavlenko, A. M. Regularities of boiling-up of emulsified liquids / A. M. Pavlenko, B. I. Basok // Heat Transfer Research, - 2005. 36 (5), - pp. 419.

[2] Yakushev, V. S. Sovremennoe sostoyanie gazogidratnyh tekhnologiy / V. S. Yakushev, V. G. Kvon, Yu. A. Gerasimov, V. A. Istomin. - Moscow: OOO «IRTS Gazprom», - 2008. - 88 p.

[3] Takeya, S. Self-preservation effect and dissociation rates of CH4 hydrate / S. Takeya, T. Ebinuma, T. Uchida et al. // J. Crystal Growth. - 2002. - V.237-239. - P. 379-382.

[4] Stem, L.A. Temperature, pressure and composition effects on anomalous or "self preservation of gas hydrates / L.A. Stem, S. Circone, S.H. Kirby, W.B. Durham // Can. J. Phys. - 2003. - V.81. - P. 271-283.

[5] Behkish, A. Novel correlations for gas holdup in large-scale slurry bubble column reactors operating under elevated pressures and temperatures / A. Behkish, R. Lemoine, R. Oukaci, B. I. Morsi // Chemical Engineering Journal. - 2006. Vol. 115, - P. 157-171.

[6] Shahrzad Hashemi Dynamic Simulation of Gas Hydrate Formation in an Agitated Three-Phase Slurry Reactor / Hashemi Shahrzad, Macchi Arturo, Servio Phillip // The 12th International Conference on Fluidization - New Horizons in Fluidization Engineering. - 2007. Art. 39. - P. 329-336.

[7] Shagapov, V. Sh. K teoryi rosta parovyh puzyr'kov v metastabil'noy zhidkosti / V. Sh. Shagapov, V. V. Koledin // Teplofizika vysokih temperatur. - 2013. - Vol. 51, Issue 4. - P. 543-551. doi: $10.7868 / \mathrm{s} 0040364413040212$

[8] Veretel'nik, T. I. Matematicheskoe modelirovanie kavitatsionnogo potoka zhidkosti v himikotekhnologicheskoy sisteme / T. I. Veretel'nik, Yu. N. Difuchin // Visnyk ChDTU. - 2008. - Issue 3. - P. 82-85.

[9] Aktershev, S. P. Modelirovanie vskipaniya metastabil'noy zhidkosti pri nalichii frontov ispareniya / S. P. Aktershev, V. V. Ovchinnikov // Sovremennaya nauka: issledovaniya, idei, rezul'taty, tekhnologi. - 2013. Issue 1. - P. 77-82.

[10] Nigmatulin, R. I. Dinamika i teplomassoobmen parogazovyh puzyr'kov s zhidkost'yu / R. I. Nigmatulin, N. S. Habeev // Nekotorye voprosy mekhaniki sploshnoy sredy. - Moscow: In-t mekhaniki MGU, 1978. - P. 229-243. 
[11] Kulinchenko, V. R. Peredumovy stvorennia matematychnoi modeli - osnovni polozhennia i rivniannia rukhu Releia / V. R. Kulinchenko, V. L. Zavialov, T. H. Mysiura // Naukovi pratsi Natsionalnoho universytetu kharchovykh tekhnolohyi. - 2007. - Issue 22. - P. 36-41.

[12] Dolinskiy, A. A. Teoreticheskoe obosnovanie printsipa diskretno-impul'snogo vvoda energyi. Model' dinamiki odinochnogo parovogo puzyr'ka [Text] / A. A. Dolinskiy, G. K. Ivanitskiy // Prom. teplotekhnika. 1995. - Vol. 17, Issue 5. - P. 3-28.

[13] Pavlenko, A.M., Basok, B.I. (2005). Kinetics of water evaporation from emulsions / A.M. Pavlenko, B.I. Basok // Heat Transfer Research. 36, (5), - P. 425-430.

[14] Butcher, J. C. Numerical Methods for Ordinary Differential Equations [Text] / J. C. Butcher - New York: John Wiley \& Sons, - 2008. - pp. 482.

[15] Kushnir, S. V. Barbotazhni khimichni efekty: yikh vydy, mekhanizmy vynyknennia ta heokhimichni proiavy / S. V. Kushnir, M. V. Kost, R. P. Kozak // Naukovo-tekhnichni visti. - 2016. - Issue 3 (20). - P. 30-47.

[16] Ermolaeva, G. A. Tekhnologiya i oborudovanie proizvodstva piva i bezalkogol'nyh napitkov: ucheb. / G. A. Ermolaeva, P. A. Kolcheva. - Moscow: IRPO; Izd. tsentr «Akademiya», - 2000. - 416 p.

[17] Mosin, O. V. Fiziko-himicheskie osnovy opresneniya morskoy vody / O. V. Mosin // Soznanie i fizicheskaya real'nost'. - 2012. - Issue 1. - P. 19-30.

[18] Semenov, M. E. Sintez gidratov gazov v laboratornyh usloviyah: XVII mezhdunar. nauch.-prakt. konf / M. E. Semenov, E. Yu. Shits // Tekhnicheskie nauki - ot teoryi k praktike. - Novosibirsk: SibAK, - 2013. - P. $55-61$.

[19] Okutani, K. Surfactant effects on hydrate formation in an unstirred gas/liquid system: An experimental study using methane and sodium alkyl sulfates / K. Okutani, Y. Kuwabara, Y. Mori // Chemical Engineering Science,. - 2008. V.63. P. 183-194

[20] Mel'nikov, V. P. Relaksatsionnyy YAMR-analiz fazovyh prevrashcheniy vody v dispersnoy sisteme voda/gidrat freona -12/uglevodorod pri dissotsiatsyi gidrata / V. P. Mel'nikov, L. C. Podenko, A. N. Nesterov, A. M. Reshetnikov // DAN. - 2010. - Vol. 433, Issue 1. - P. 59-61.

Надійшла 06.02.2019

Received 03.02.2019 